\title{
Research Paper Trend and change point analysis of rainfall of various districts of Bihar
}

See end of the paper for authors' affiliations

Correspondence to :

\section{NITIN VARSHNEY}

ICAR-Indian Agricultural Research Institute, NEW DELHI, INDIA

Email : nitin.ankur12@ gmail.com

Paper History :

Received : 09.05.2017;

Revised : 14.08.2017;

Accepted : 21.08 .2017
ABSTRACT : Precipitation trend analysis has been of great concern during the past century because of the attention given to global climate change by the scientific community. The study of precipitation trends is critically important for a country like India whose food security and economy are dependent on the timely availability of water such as 83 per cent water used for agriculture sector, 12 per cent for industry sector and only 5 per cent for domestic sector. So the present study attempted to know the trend of rainfall of five different districts viz., Araria, Kishanganj, Madhubani, Purnia and West Champaran of Bihar for the period (1950-2000). The change point analysis has been critically analyzed for observing any change. For this purpose, rainfall data have been collected from respective meteorological stations. Statistical analysis of trend subjected to Mann-Kendall test, Sen's slope testand change point analysis.

KEY WORDS : Mann-Kendall test, Pettitt change point analysis, Sen's slope

How To Cite This PAPer : Varshney, Nitin and Satpathy, Subhrajit (2017). Trend and change point analysis of rainfall of various districts of Bihar. Internat. Res. J. Agric. Eco. \& Stat., 8 (2) : 393-400, DOI : 10.15740/HAS/ IRJAES/8.2/393-400. 